\title{
Prevalensi Dermatitis Ulseratif pada Tukik Lekang yang Dipelihara di Turtle Conservation and Education Centre Serangan
}

\author{
(PREVALENCE OF ULCERATIVE DERMATITIS IN OLIVE RIDLEY HATCHLINGS \\ REARED AT TURTLE CONSERVATION AND EDUCATION CENTRE SERANGAN)
}

\author{
Annabella Ruth Wijaya ${ }^{1}$, Ida Bagus Windia Adnyana², I Made Kardena ${ }^{2}$ \\ ${ }^{1}$ Mahasiswa Program Pendidikan Dokter Hewan, Fakultas Kedokteran Hewan Denpasar \\ ${ }^{2}$ Lab Patologi Fakultas Kedokteran Hewan, Universitas Udayana \\ Jalan PB Sudirman, Denpasar-Bali, \\ Email: annabella.ruth.wijaya@gmail.com
}

\begin{abstract}
ABSTRAK
Dermatitis ulseratif adalah penyakit yang paling sering menjangkiti penyu dan/atau tukik yang dipelihara di kolam-kolam penampungan, termasuk di Turtle Conservation and Education Centre (TCEC), Serangan. Penelitian dilakukan untuk mengetahui prevalensi, gambar patologi, dan lokasi jejas dermatitis ulseratif pada tukik lekang yang dipelihara di TCEC Serangan, serta perbedaan indeks kondisi tubuh tukik lekang penderita dermatitis ulseratif dengan tukik yang sehat. Prevalensi diketahui dengan menghitung jumlah tukik lekang penderita yang dibandingkan dengan total tukik di TCEC. Morfometri (straight carapace length, straight carapace width, curved carapace length, curved carapace width) dan berat badan tukik diukur untuk mengetahui indeks kondisi tubuh tukik lalu perbedaan indeks kondisi tubuh dibandingkan dengan Uji - T tidak berpasangan. Sampel jaringan kulit diproses menjadi preparat dan diwarnai dengan pewarnaan rutin Hematoxylin eosin(HE). Hasil penelitian ini yaitu : prevalensi dermatitis ulseratif pada tukik lekang di TCEC adalah 16,2\%, ditemukan jejas luka dengan kerak kekuningan berdiameter $2 \mathrm{~mm}$ hingga $2 \mathrm{~cm}$ dan secara mikroskopis ditemukan infiltrasi heterofil dan sel mononuklear pada dermis kulit yang disertai dengan erosi, hiperkeratosis parakeratosis, dan materi nekrosis yang berisi debris sel. Jejas paling sering ditemukan pada area leher (63,04\%), diikuti dengan flippers, kepala, kulit dekat karapas, kelopak mata, dan area leher dan flippers secara bersamaan. Terdapat perbedaan indeks kondisi tubuh yang sangat nyata antara tukik lekang penderita dengan yang sehat, dimana rerata indeks kondisi tubuh tukik penderita lebih besar dari yang sehat. Perlu dilakukan perbaikan manajemen pemeliharaan tukik di TCEC.
\end{abstract}

Kata kunci: dermatitis ulseratif; indeks kondisi tubuh; prevalensi; tukik lekang

\section{ABSTRACT}

Ulcerative dermatitis is a disease that most commonly affects turtles and/or hatchlings that are kept in ponds, including in Turtle Conservation and Education Center (TCEC), Serangan. A study was conducted to determine the prevalence, pathology, and lesion location of ulcerative dermatitis in olive ridley hatchlings reared in TCEC Serangan, also the differences of the body condition index of olive ridley hatchlings with ulcerative dermatitis and healthy ones. Prevalence was determined by counting sick hatchlings compared with the total number of hatchlings at TCEC. Morphometry (straight carapace length, straight carapace width, curved carapace length, curved carapace width) and body weights were measured to determine the body condition index, and then body index differences were compared with unpaired T-Test. Skin tissue samples were processed into pathology slides and routinely staining of hematoxylin eosin (HE). The prevalence of ulcerative dermatitis in olive ridley hatchlings at TCEC was $16.2 \%$. Crusty-yellow wound lesions of $2 \mathrm{~mm}$ to $2 \mathrm{~cm}$ in diameter were found and microscopically there were heterophils and mononuclear cells infiltration in skin dermis accompanied by erosion, parakeratosis, and necrotic material containing cell debris. Lesions were found mostly on neck area (63.04\%), followed by flippers, head, skin near carapace, eyelids, and neck area with flippers combined. There was a very significant difference in body condition index between suffered hatchlings with healthy ones, where the average body condition index of suffered hatchlings were greater than healthy ones. Rearing management should be fixed.

Keywords: ulcerative dermatitis; body condition index; prevalence; olive ridley hatchling 


\section{PENDAHULUAN}

Pulau Bali merupakan destinasi pariwisata yang terkenal akan pantaipantainya yang masih belum banyak dijamah publik. Namun pantai-pantai tersebut merupakan habitat dari berbagai spesies hewan, termasuk tempat bertelur bagi penyu laut. Kegiatan pariwisata dapat membuat susana bertelur penyu menjadi tidak kondusif. Turtle Conservation and Education Centre (TCEC) adalah lokasi penangkaran penyu laut yang, sesuai namanya, melaksanakan kegiatan konservasi dan edukasi publik mengenai penyu laut. Telur-telur penyu dipindahkan dan ditetaskan di lokasi ini. Tukik yang baru menetas sebagian besar dilepaskan ke laut, dan sebagian kecil tetap dipelihara sebagai sarana edukasi publik. Upaya pemeliharaan ini terkadang dapat menyebabkan kondisi patologis, salah satunya adalah dermatitis ulseratif.

Dermatitis ulseratif adalah penyakit yang paling sering menjangkiti penyu dan/atau tukik yang dipelihara di kolamkolam penampungan (Muñoz et al., 2013; Orós et al., 2005). Selain itu, penyakit ini memiliki angka mortalitas yang tinggi sehingga penyakit ini digolongkan sebagai penyakit yang berbahaya dan penting dalam konservasi penyu di habitat buatan. Namun, informasi mengenai dermatitis ulseratif pada tukik yang dipelihara di TCEC Serangan sangat minimal. Sementara itu, status terancam punah yang diberikan pada satwa jenis ini mengharuskan agar semua tindakan pemeliharaan yang dilakukan harus berkontribusi positif terhadap upaya konservasinya. Dengan demikian, kondisi patologis yang muncul akibat proses pemeliharaannya harus terindentifikasi dengan baik sehingga upaya pencegahan dan kontrol bisa dilakukan dengan memadai (Lutz et al., 2003).

Karena itu, dilakukan penelitian untuk mengetahui prevalensi, gambaran patologi, dan lokasi jejas dermatitis ulseratif pada tukik lekang yang dipelihara di TCEC Serangan serta perbedaan indeks kondisi tubuh antara tukik penderita dermatitis ulseratif dengan yang sehat.

\section{METODE PENELITIAN}

Objek penelitian yang digunakan adalah tukik lekang berusia tiga sampah delapan minggu yang dipelihara di TCEC Serangan. Bahan-bahan yang digunakan adalah NBF 10\%, alkohol 70\% hingga absolut, etanol absolut, parafin, toluena, Harris Hematoxylin-Eosin, entellan, dan xylol. Alat-alat yang digunakan yaitu jangka sorong (Kenmaster Sigmat 6"), pita pengukur (Yiwu Centi, $300 \mathrm{~cm}$ ), timbangan digital (Kris Chef model EK9150), scalpel, pinset, toples kecil berdimensi (10 buah), label, kamera digital, tissue processor, tissue cassette, trimming tray, parafin set, embedding set, mikrotom, waterbath, hotplate, glass slide, cover glass, staining jar dan mikroskop binokuler.

Jenis penelitian ini adalah observasional dengan kajian cross sectional study. Gambaran patologi dan lokasi jejas yang diamati pada penelitian ini dideskripsikan dengan deskriptif kualitatif. Perbedaan indeks kondisi tubuh antara tukik sehat dan penderita dibandingkan dengan Uji - $\mathrm{T}$ tidak berpasangan dalam program IBM ${ }^{\circledR}$ SPSS ${ }^{\circledR}$ Statistics versi 22.0.0.0. Penelitian dilakukan di Turtle Conservation and Education Center (TCEC), Serangan yaitu pada bulan Oktober 2016.

Prevalensi dermatitis ulseratif diketahui dengan menghitung jumlah tukik penderita yang kemudian jumlahnya dibandingkan dengan total tukik yang ada di TCEC. Pengukuran dilakukan pada semua tukik dan mencakup berat badan dan morfometri yang meliputi Straight Carapace Length (SCL), Straight Carapace Width (SCW), Curved Carapace Length (CCL), dan Curved Carapace Width (CCW). SCL dan SCW diukur menggunakan jangka sorong sedangkan CCL dan $\mathrm{CCW}$ diukur menggunakan pita pengukur. Berat badan tukik diukur menggunakan timbangan digital. Indeks kondisi tubuh dihitung dengan persamaan: 
$\mathrm{BCI}=\left(\left[\right.\right.$ berat $\left.\left.(\mathrm{kg}) / \mathrm{SCL}(\mathrm{cm})^{3}\right] \times 10000\right)$ (Bjorndal et al., 2000). Sampel jaringan kulit diambil dari tukik lekang yang sudah mati dan terdeteksi menderita dermatitis ulseratif secara klinis. Sampel jaringan kemudian diproses menjadi preparat dan diwarnai secara rutin di Laboratorium Patologi, Fakultas Kedokteran Hewan, Universitas Udayana.

\section{HASIL DAN PEMBAHASAN}

\section{Hasil}

Terdapat 284 ekor tukik lekang di TCEC Serangan yang dipelihara dalam kolam-kolam menurut kelompok umurnya. Dalam tiap kolam, tukik ditempatkan di dalam keranjang plastik berlubang yang diberi pelampung dan setiap keranjang diisi 2-3 ekor tukik. Jumlah tukik lekang berdasarkan kelompok umurnya disajikan pada Tabel 1.

Tabel 1. Jumlah Tukik Lekang (Lepidochelys olivacea) yang Dipelihara di TCEC, Serangan selama periode Agustus Oktober 2016

\begin{tabular}{cc}
\hline Umur & Jumlah Tukik Lekang \\
\hline 0-3 Minggu & 74 \\
3-6 Minggu & 60 \\
>6 Minggu & 150 \\
\hline Total Tukik & 284 \\
\hline
\end{tabular}

Ditemukan bahwa 46 ekor $(16,2 \%)$ tukik lekang menderita dermatitis ulseratif. Hasil tersebut terbilang rendah jika dibandingkan dengan penelitian-penelitian lainnya, seperti penelitian Orós et al. (2005) dan Bailey (2008). Pada penelitian Bailey (2008), tukik dipelihara bersama di kolam hingga mereka saling menggigit. Luka gigitan berkembang menjadi dermatitis ulseratif. Lalu pada penelitian Orós et al. (2005), penyu yang terdampar umumnya memiliki kondisi kesehatan yang buruk (Chaloupka et al., 2008; Orós et al., 2016). Selama proses terdampar, penyu juga dapat terluka sehingga secara klinis terdeteksi menderita dermatitis ulseratif. Di sisi lain, tukik di TCEC diberi perlakuan berupa penempatan tukik dalam keranjang yang mengurangi kontak fisik antar tukik sehingga gigitan antar tukik yang sering terjadi juga menurun. Namun, tukik-tukik yang ditempatkan dalam keranjang yang sama masih dapat saling menggigit sehingga kasus dermatitis ulseratif masih terjadi.

Jika prevalensi dipilah sesuai kelompok umur, maka didapati prevalensi yang berbeda-beda dan data tersebut disajikan pada Grafik 1.

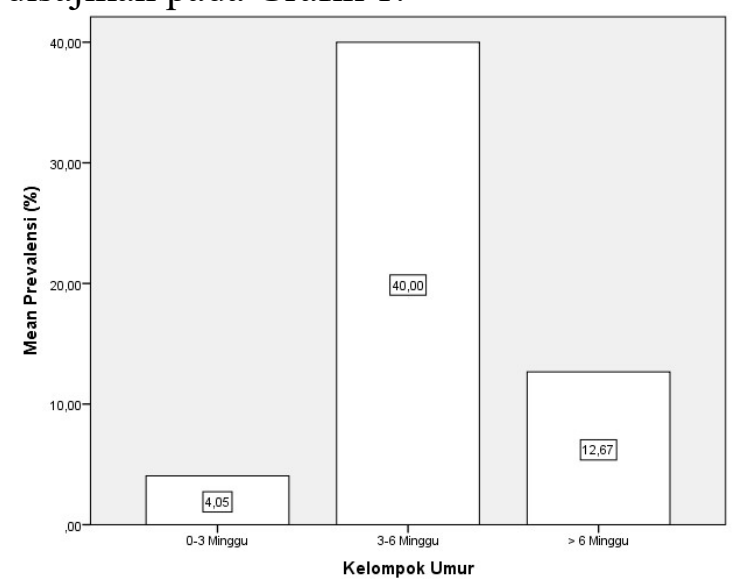

Grafik 1. Prevalensi Dermatitis Ulseratif pada Tiap Kelompok Umur Tukik Lekang (Lepidochelys olivacea)

Prevalensi tertinggi adalah pada kelompok umur 3-6 minggu karena tukik dengan agresif berebut makanan dan saling menggigit. Tukik lekang yang dipelihara memiliki kecenderungan untuk menjadi kanibal (Ernst dan Lovich, 2009; Lutz et al., 2003). Pada usia lebih dari 6 minggu, prevalensi dermatitis ulseratif mengalami penurunan karena tukik-tukik telah dilepas ke laut atau mati hingga tidak termasuk hitungan. Penyebab lain adalah turunnya agresi tukik pada usia tersebut. Prevalensi paling rendah terdapat pada kelompok umur 0-3 minggu karena tukik masih memiliki kantung kuning telur sebagai sumber makanannya selama 15 hari pertama sehingga tukik belum berebut makanan atau saling menggigit dengan agresif (Lutz et al., 2003). Secara patologi anatomi, jejas terlihat berupa luka trauma yang terkadang tertutupi kerak putih kekuningan. Jejas berdiameter antara 2-5 $\mathrm{mm}$ dan ada yang dapat mencapai dua $\mathrm{cm}$ serta tersebar secara multifokal (Gambar 1). 

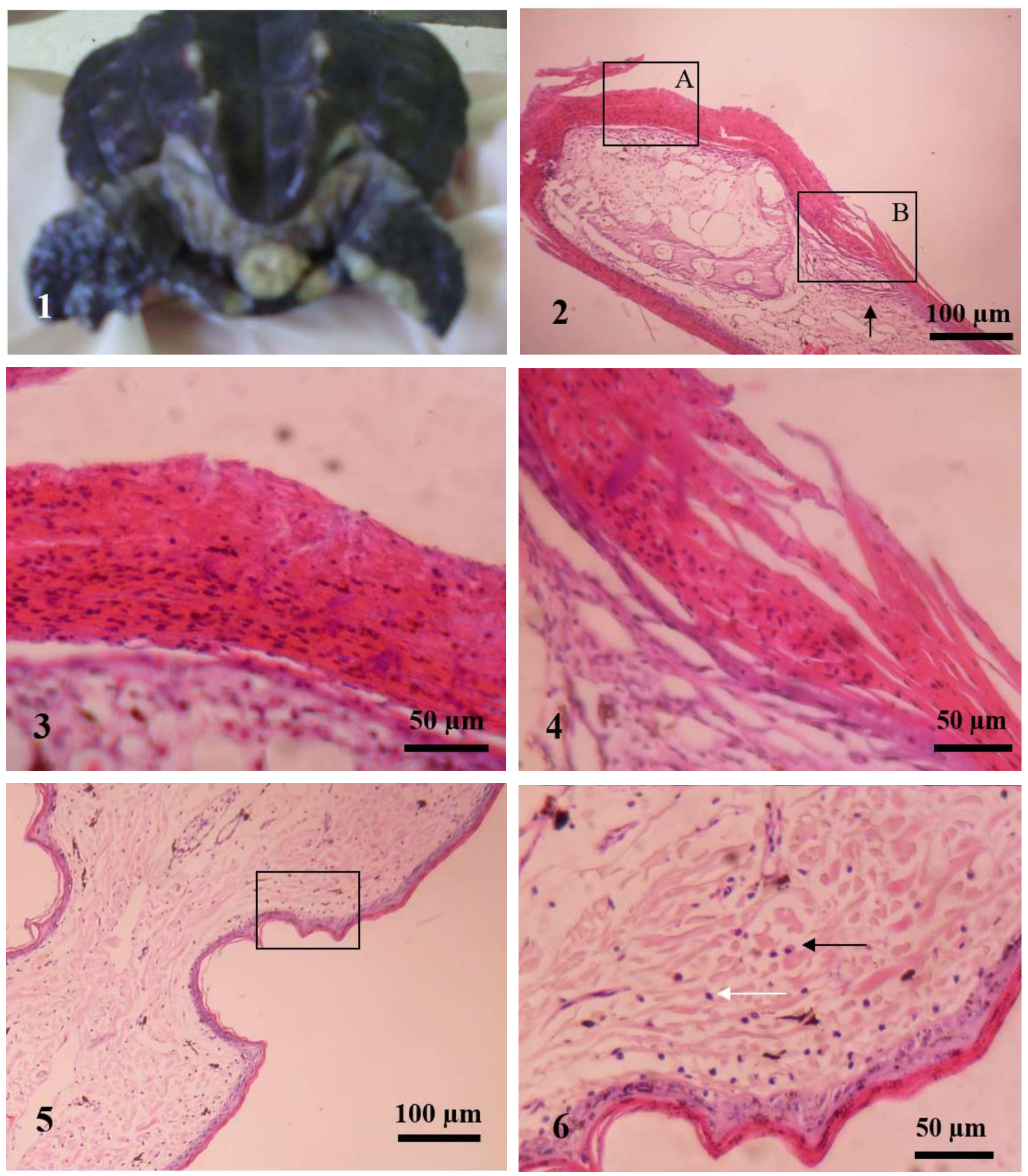

Keterangan: 1. Jejas pada Kulit Ekor dan Flipper Kiri Tukik C. Gambar menunjukkan luka dengan diameter hingga dua $\mathrm{cm}$ yang tertutupi kerak putih kekuningan. 2. Gambaran Histopatologi Jejas di Kulit Flipper Kanan Tukik A. Gambar menunjukkan hiperkeratosis parakeratosis (daerah kotak A) dan disintegrasi epitel / erosi (daerah kotak B) serta lapisan hasil proses penyembuhan (tanda panah) (100x, HE). 3. Perbesaran Daerah Kotak A dari Gambar 2. Gambar menunjukkan perbesaran yang lebih kuat pada hiperkeratosis parakeratosis (400x, HE). 4. Perbesaran Daerah Kotak B dari Gambar 2. Gambar menunjukkan perbesaran yang lebih kuat pada disintegrasi epitel atau erosi (400x, HE). 5. Gambaran Histopatologi Jejas di Kulit Flipper Kiri Tukik B. Gambar menunjukkan infiltrasi sel-sel radang (daerah kotak) (100x, HE). 6. Perbesaran dari Daerah Kotak Gambar 5. Gambar menunjukkan infiltrasi heterofil (tanda panah hitam) dan sel mononuklear (tanda panah putih) (400x, HE). 

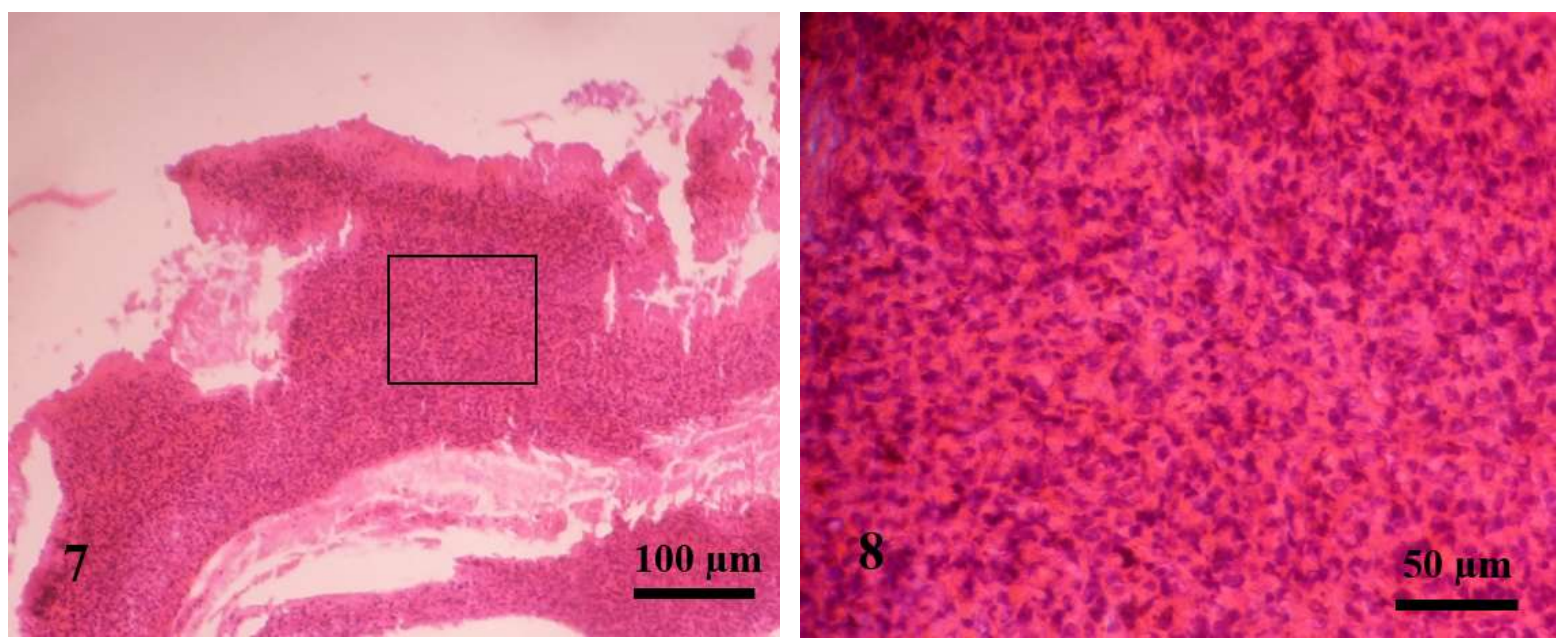

Keterangan: 7. Gambaran Histopatologi Jejas di Kulit Ekor Tukik C. Gambar menunjukkan debris sel yang mengindikasikan nekrosis (daerah kotak) (100x, HE). 8. Perbesaran dari Daerah Kotak dari Gambar 7. Gambar menunjukkan perbesaran yang lebih kuat pada debris sel (400x, $\mathrm{HE})$

\section{Pembahasan}

Jejas dapat ditemukan pada flippers, leher, kepala, kelopak mata, kulit yang berbatasan dengan karapas, dan ekor. Pemeriksaan mikroskopis menunjukkan bahwa sudah terjadi proses penyembuhan yang ditandai dengan adanya lapisan epitel yang baru (Gambar 2). Ditemukan adanya radang ringan - sedang yang ditandai dengan infiltrasi granulosit, yaitu heterofil dan sel-sel mononuklear di area dermis kulit tukik (Gambar 5 dan 6). Erosi dan hiperkeratosis parakeratosis ditemukan pada stratum korneum epidermis (Gambar 2, 3, dan 4). Reruntuhan sel (debris) yang mengindikasikan terjadinya nekrosis juga teramati pada area epidermis (Gambar 7 dan 8).

Perubahan-perubahan patologi yang ditemukan tidak sedramatis penelitian Orós et al. (2005) dan Muñoz et al. (2013). Hal ini disebabkan usia tukik yang masih muda dan sifat dermatitis ulseratif yang kronis dan akumulatif sehingga perubahanperubahan yang ditemukan belum tampak secara jelas (Muñoz et al., 2013; Orós et al., 2005). Penempatan tukik dalam keranjang juga dapat berpengaruh.

Saat jejas dipetakan menurut lokasinya, jejas dermatitis ulseratif paling banyak ditemukan di area leher tukik, yaitu sebanyak $63,04 \%$. Sebanyak $19,57 \%$ jejas ditemukan pada flippers tukik, diikuti dengan $6,52 \%$ jejas yang ditemukan pada area kepala dan juga pada area kulit yang berbatasan dengan karapas. Sebanyak 2,17\% jejas ditemukan pada kelopak mata, dan juga pada flippers dan leher secara bersamaan. Jejas yang ditemukan di area leher, kepala, dan kelopak mata disebabkan oleh perebutan makanan. Pemberian pakan tanpa ditakar dan diberikan pada satu lokasi dalam keranjang sehingga tukik saling gigit untuk mendapatkan makanan. Sedangkan jejas di flippers dan kulit dekat karapas disebabkan oleh sifat agresif tukik dimana tukik akan menggigit anggota tubuh tukik lain yang mudah dijangkau.

Hasil penghitungan terhadap indeks kondisi tubuh tukik menunjukkan bahwa rerata indeks kondisi tubuh tukik lekang yang menderita dermatitis ulseratif adalah $1,8 \pm 0,35$ dengan kisaran $0,89-2,66$. Sementara itu, rerata indeks kondisi tubuh tukik lekang yang tidak menderita dermatitis ulseratif adalah $1,6 \pm 0,41$ dengan kisaran $0,74-2,81$. Uji T tidak berpasangan menunjukkan bahwa kedua nilai rerata tersebut berbeda sangat nyata $(\mathrm{P}<0,01)$. Rerata indeks kondisi tubuh tukik sakit secara sangat signifikan lebih besar daripada tukik yang sehat karena usia tukik 
yang masih muda. Jadi, sama dengan gambaran patologi yang tampak, dampak dermatitis ulseratif terhadap kondisi tubuh penyu membutuhkan waktu yang lama untuk muncul (Muñoz et al., 2013). Tukik yang mendapat makanan akan digigit oleh tukik yang tidak mendapat makanan dalam proses perebutan makanan hingga tukik sakit yang memiliki rerata indeks kondisi tubuh yang lebih tinggi daripada tukik sehat.

\section{SIMPULAN DAN SARAN}

\section{Simpulan}

Prevalensi dermatitis ulseratif pada tukik lekang yang dipelihara di Turtle Conservation and Education Centre, Serangan adalah $16,2 \%$, dengan gambaran patologi dermatitis ulseratif berupa jejas luka dengan kerak kekuningan berdiameter dua $\mathrm{mm}$ hingga dua $\mathrm{cm}$ dan secara mikroskopis ditemukan infiltrasi heterofil dan sel mononuklear pada area dermis kulit yang disertai dengan erosi dan parakeratosis pada epidermis serta materi nekrosis yang berisi debris sel. Lokasi jejas paling sering $(63,04 \%)$ terdapat pada area leher yang diikuti dengan $19,57 \%$ pada flippers. Sebanyak 6,52\% lesi terdapat pada area kepala dan kulit yang berbatasan dengan karapas dan sebanyak 2,17\% lesi terdapat pada kelopak mata, flippers dan area leher secara bersamaan. Terdapat perbedaan indeks kondisi tubuh yang sangat nyata $(\mathrm{P}<0,01)$ antara tukik lekang penderita dermatitis ulseratif dengan tukik lekang yang sehat.

\section{Saran}

Perlu dilakukan perbaikan manajemen pemeliharaan tukik di TCEC Serangan, yaitu pencatatan umur yang lebih akurat, penempatan hanya seekor tukik dalam keranjang, pembatasan jumlah tukik yang dipelihara, dan penakaran jumlah pakan yang diberikan. Selain itu, perlu dilakukan penelitian lebih lanjut untuk membahas dampak dermatitis ulseratif terhadap indeks kondisi tubuh tukik lekang pada usia 3-8 minggu.

\section{UCAPAN TERIMA KASIH}

Penulis mengucapkan terima kasih kepada pihak Turtle Conservation and Education Centre, Serangan atas bantuan berupa arahan selama penelitian berlangsung.

\section{DAFTAR PUSTAKA}

Ario R, Wibowo E, Pratikto I Fajar S, 2016. Pelestarian Habitat Penyu dari Ancaman Kepunahan di Turtle Conservation And Education Center (TCEC), Bali. J. Kelautan Tropis. 19(1): 60-66.

Bailey T. 2008. Mortality at a hawksbill turtle (Eretmochelys imbricata) Rearing Center. Wildlife Middle East News. 3(2): 1-3.

Berata IK, Winaya IBO, Adi AAAM, Adnyana IBW. 2015. Patologi Veteriner Umum. Swasta Nulus. Denpasar

Bjorndal KA, Bolten AB, Chaloupka MY. 2000. Green turtle somatic growth model: evidence for density dependence. Ecol. Appl. 10: 269-282.

Chaloupka M, Work TM, Balazs GH, Murakawa SKK, Morris R. 2008. Causespecific temporal and spatial trends in green sea turtle strandings in the Hawaiian Archipelago (1982-2003). Mar. Biol. 154: 887-898.

Ernst CH, Lovich JE. 2009. Turtles of the United States and Canada. Ed. 2. JHU Press. Baltimore

Lutz PL, Musick JA, Wyneken J. 2003. The Biology of Sea Turtles. Vol. 2. CRC Press. Florida

Markey BK, Leonard FC, Archambault M, Cullinane A, Maguire D. 2013. Clinical Veterinary Microbiology. Ed. 2. Mosby Elsevier. London

Muñoz FA, Estrada-Parra S, Romero-Rojas A, Gonzales-Ballesteros E, Work TM, Villaseñor-Gaona H, Estrada-Garcia I. 2013. Immunological Evaluation of the Captive Green Sea Turtle (Chelonia mydas) with Ulcerative Dermatitis. J. Zoo and Wildlife Med. 44(4): 837-844.

Orós J, Torrent A, Calabuig P, Déniz S. 2005. Diseases and Causes of Mortality among Sea Turtles Stranded in the 
Canary Islands, Spain (1998-2001). Dis. Aquat. Org. 63: 13-24.

Orós J, Montesdeoca N, Camacho M, Arencibia A, Calabuig P. 2016. Causes of Stranding and Mortality, and Final Disposition of Loggerhead Sea Turtles (Caretta caretta) Admitted to a Wildlife Rehabilitation Center in Gran Canaria Island, Spain (1998-2014): A LongTerm Retrospective Study. PLoS ONE. 11(2): e0149398.

Reavill DR, Melloy M, Schmidt ER. 2004. Reptile mycotic infections from the literature and 55 cases, In : Proceedings. Association of Reptilian and Amphibian Veterinarians. Naples, USA, 8-11 Mei 2004. Pp: 62-71.

Swain P, Behura A, Dash S. 2007. Serum antibody response of Indian major carp, Labeo rohita, to three species of pathogenic bacteria; Aeromonas hydrophila, Edwardsiella tarda and Pseudomonas fluorescens. Vet. Immunol. Immunopathol. 117:137-141. 